\title{
子宮体癌早期例に対する腹腔鏡下手術の経験
}

三重県立総合医療センター産婦人科 ${ }^{1)}$ 、市立四日市病院産婦人科 ${ }^{2}$ 、三重大学 ${ }^{32}$ 田中浩彦 ${ }^{1)}$ 、鳥谷部邦明 ${ }^{1)}$ 、千田時弘 ${ }^{1)}$ 、井澤美穂 ${ }^{1)}$ 、吉田佳代 ${ }^{1)}$ 、 朝倉徹夫 ${ }^{1)}$ 、谷口晴記 ${ }^{1)}$ 、長尾賢治 ${ }^{2)}$ 、近藤英司 ${ }^{3)}$

\section{Preliminary study of laparoscopic surgery for early-stage endometrial cancer}

\author{
H Tanaka ${ }^{1)}$, K Toriyabe $^{1)}$, T Senda ${ }^{1)}$, M Izawa ${ }^{1)}$, K Yoshida $^{1)}$, \\ $\mathrm{T}_{\text {Asakura }}{ }^{1)}, \mathrm{H}_{\text {Taniguchi }}{ }^{1)}, \mathrm{K} \mathrm{Nagao}^{2)}, \mathrm{E} \mathrm{Kondo}^{3)}$ \\ Department of Obstetrics and Gynecology, Mie Prefectural General Medical Center ${ }^{1)}$, \\ Department of Obstetrics and Gynecology, Yokkaichi Municipal Hospital2), \\ Department of Obstetrics and Gynecology, Mie University ${ }^{3)}$
}

\begin{abstract}
Objective: The aims of this study were to evaluate the use of laparoscopic surgery for early-stage endometrial cancer, with regard to the feasibility, safety, and outcomes of the procedures.

Methods: Six patients with clinical stage IB, G1-2 endometrial cancer diagnosed preoperatively underwent laparoscopy. The surgical procedures included hysterectomy, salpingo-oophorectomy, and pelvic lymphadenectomy. The outcomes and operative procedures were evaluate.

Result(s): All 6 patients were successfully treated using laparoscopy. The mean operative time was 318 minutes (range, 265-387 minutes), mean amount of bleeding was $304 \mathrm{~g}$ (range, 100-664 g), mean number of excised lymph nodes was 35.8 (range, 22-50), and mean duration of postoperative hospitalization was 5.7 days (range, 5-7 days). Severe adverse events were not encountered.

Conclusion(s): Laparoscopic surgery that is based on the procedures for total laparoscopic hysterectomy for benign disease and for laparotomy for malignant disease appears to be feasible for early-stage endometrial cancer, if care is taken with the anatomical structures in the retroperitoneal space.
\end{abstract}

Key Words: laparoscopy, endometrial cancer, pelvic lymphadenectomy

\section{はじめに}

子宮体癌手術における後腹膜リンパ節郭清の範 囲は施設により異なるが、早期例においては縮小 手術が実施される傾向にある。当科では現在、術 前T1a-b、G1-2（子宮体癌取り扱い規約）と判断 した症例において傍大動脈リンパ節郭清の省略を 検討している。根治性を損なわず、低侵襲にリス ク因子を評価することは重要と思われる。また minimally invasive surgeryの導入は、術後の回
復、社会復帰を早め、罹患女性のQOLを高める ことに貢献するものと考える。今回我々は倫理委 員会の承認を得て、2010年より子宮体癌早期例に 対する腹腔鏡下手術の導入を開始した。

導入にあたり、腹腔鏡下でのリンパ節摘出や悪 性疾患に対する子宮全摘術を意識して、開腹によ る骨盤リンパ節郭清や良性疾患に対する total laparoscopic hysterectomyを行った。同時期に 多数例を経験しているエキスパート医師の手術を 見学した。 


\section{対象と方法}

術前の精查により、子宮内膜癌G1-2、子宮体部 に限局し、筋層 $1 / 2$ までの浸潤と判断された、挙 児希望を有さない25-75歳の女性を対象とした。 また、BMI35未満の、重篤な合併症を有さない全 身麻酔および腹腔鏡下手術に耐えうる症例とし た。子宮筋腫、子宮腺筋症にて胵からの子宮搬出 に支障をきたすような大きな子宮は対象から除外 した。遠隔転移なく、筋層浸潤 $1 / 2$ 未満の症例で あっても、細胞診上著明な細胞異型の見られる症 例や、組織診上漿液性腺癌や明細胞腺癌などtype 2腺癌が疑われる場合は、これを除外した。

手術を行うにあたり、まず2011年 3 月に当院倫 理委員会の承認を得、また同 7 月に厚労省の先進 医療の承認を得て、現在まで症例数を積み重ねて きている。今回の対象症例は倫理委員会承認後の 2011年 3 月以降 2012 年 2 月末までの 6 例を対象と した。

術中、子宮外への転移巣を疑う部位が見られた 場合は術中迅速検查を行うこととした。出血、合 併症等により腹腔鏡下手術の継続が困難と判断さ れた場合や、上記迅速診断により子宮外に転移が 確認された場合は、速やかに開腹手術に移行する こととした。摘出標本よりリスク因子が抽出され た場合、子宮体癌ガイドラインに基づき、術後療 法を考慮した。リスク因子が検出されなかった場 合、そのまま外来経過観察とし、その方法はガイ ドライン1)に準じた。

文書による手術説明を行い、インフォームドコ ンセントを得た後に施行した。原則として自己血 採血後に手術を施行した。

術式は以下のとおりである。

約10度骨盤高位の砕石位とし、気腹圧は約 8 $\mathrm{mmHg}$ 、腟内に癌細胞を散布しないよう外子宮 口を0-バイクリルで綘縮した後、手術を実施した。 ポートの配置を良性疾患と同様のダイヤモンド型 4 ポートとし、単純子宮全摘（TLH）拈よび両 側付属器切除術（BSO）を施行した。

腹水を採取し細胞診提出後、両側卵管をリガシ ユア ${ }^{\circledR}$ (コヴィディエン、ダブリン［アイルラン ド]）にてシーリングし、腹腔内への癌細胞の散 布を防いだ。子宮マニピュレーターは使用せず TLHを施行した。膀胱剥離の際に、臸パイプを 扱入して子宮頸部を挙上。子宮頸部㧍よび胵上部 と膀胱との間の疎性結合織を鋭的鈍的に剥離し て、膀胱を足側に下した。直針付きナイロン糸に
よる円勒帯のつり上げ2) は、上部勒帯処理時に施 行した。子宮摘出後腟カフを形成した。同時に経 腟的に体外に搬出した子宮標本に割を入れて、肉 眼で浸潤の程度を確認後、骨盤リンパ節摘出を開 始した。肉眼での筋層浸潤の確認はガイドライ ン1)に準拠した方法で行った。即ち、術前のMRI 所見と摘出子宮の肉眼的所見より浸潤が最も媣い と考えられる方向で子宮壁に割を入れ、割面を肉 眼で観察することにより筋層浸潤の深さを確認し た。筋層浸潤が深い場合は開腹し、傍大動脈リン パ節郭清を含めたstagingを行うこととしている が、今回の 6 例ではそのような症例に遭遇しなか った。

後腹膜腔を展開した後、安藤らの既報 ${ }^{2,3)} に$ 準 じて両側側臍勒帯を2-0直針ナイロン糸で吊り上 げ、膀胱側腔を展開した ${ }^{2)}$ 。臍左上約 $5 \mathrm{~cm}$ のこ ろに $12 \mathrm{~mm}$ トロッカーを 1 本追加して 5 ポートと し、牽引とリンパ節回収目的で使用した。外腸骨 血管を腸腰筋より分離し、骨盤血管、閉鎖神経、 尿管等主たる構造物を露出した。

骨盤リンパ節摘出は比較的転移頻度の高い外腸 骨節、内腸骨節、閉鎖節 ${ }^{4)}$ を中心、外爯径上節 近位側から総腸骨節遠位側までを摘出した。すな わち、遠位端は下腹壁静脈ないし無名静脈分岐部 レベルまで、近位端は総腸骨動脈と尿管の交差部 付近までを摘出した。摘出したリンパ節は金属製 のリダクションスリーブ/エクストラクター ${ }^{\circledR}$ (カ ール ストルッ、トットリンゲン [ドイッ]）を使 用して、トロッカーやその挿入口にリンパ節が直 接触れないように $12 \mathrm{~mm}$ ポートより回収した。リ ンパ節の近位端、遠位端の切除にはリガシュア ${ }^{\circledR}$ またはクリップを使用した。骨盤腹膜は無縫合と している。腸管の圧排には腹腔鏡下臓器圧排用又 ポンジであるエンドラクター ${ }^{\circledR}(川 \text { 本産業、大阪 })^{8)}$ を使用し、助手の操作を容易にした。最後にダグ ラス窩にドレーンを留置して手術を終了した。

\section{結 果}

これまでに上記術式により 6 例に施行した。手 術時間、摘出リンパ節個数、入院期間等に関して は表のと㧍りである。手術時間は平均 318 分 (265-387)、摘出したリンパ節の個数は平均 35.8 個 (22-50)、術後入院期間は平均5.7日（5-7）であった。 いずれも転移りンパ節はなかった。摘出子宮に脈 管侵襲は見られなかった。

症例 $1 、 2$ においてリンパ節摘出時間の記載が なかったため除外したが、それ以外の 4 例におけ 


\begin{tabular}{|l|r|r|r|r|r|r|}
\hline 症例 & 1 & 2 & 3 & 4 & 5 & 6 \\
\hline 術時間(m) & 310 & 296 & 265 & 387 & 359 & 293 \\
出血量 $(\mathrm{g})$ & 368 & 100 & 216 & 324 & 664 & 155 \\
摘出リンパ節数(個) & 32 & 22 & 38 & 42 & 50 & 31 \\
術後入院期間(日) & 6 & 7 & 5 & 5 & 6 & 5 \\
子宮の組織 & $\mathrm{G} 1,1 \mathrm{~b}$ & $\mathrm{G} 1,1 \mathrm{~b}$ & $\mathrm{G} 1,1 \mathrm{~b}$ & $\mathrm{G} 1,1 \mathrm{~b}$ & $\mathrm{G} 1,1 \mathrm{a}$ & $\mathrm{G} 1,1 \mathrm{~b}$ \\
合併症 & なし & なし & なし & なし & DVT & なし \\
リンパ節摘出時間 $(\mathrm{m})$ & 記載なし & 記載なし & 128 & 117 & 170 & 120 \\
\hline
\end{tabular}

るリンパ節摘出時間は平均133.3分（117-170）で あった。出血量は平均304g（100-664）で、いず れも同種血輸血は施行しなかった。症例 4 は子宮 内膜症、子宮腺筋症によると思われる過多月経か らの貧血があり、Hgb值の回復が緩徐で自己血貯 血は行わなかった。また、症例 4 は内膜症による ダグラス窩閉鎖を伴う強固な癒着のため、症例 5 は多発筋腫のためTLHに時間を要した。子宮マ ニピュレーターを使用していないため、子宮後方 の操作がやや困難であった。

合併症は、症例 5 で術後哚部静脈血栓症 (DVT) の発生があった。左下腿のヒラメ筋静脈に血栓を 生じたため、手術後 5 日目よりワーファリンの投 与を開始した。

\section{考察}

子宮体癌進行期分類の実際はsurgical staging が基本であり、そのための術式として単純子宮全 摘、両側付属器切除、骨盤抒よび傍大動脈リンパ 節郭清術を採用している施設が多い。stagingに て再発低リスク群子宮体癌（病理組織診断G1な いLG2且つ子宮体部筋層浸潤 $1 / 2$ 未満を指す）と 評価された症例では術後療法が省略されるため staging自体に意義はあるものの、上記術式は恥 骨結合上から胸骨下端付近にまで至る大きな創を 有し、cosmeticな面もさることながら手術侵襲は 大きい。痛み、出血量などの術直後直近の侵襲の みならず、下肢、下腹部リンパ浮腫の頻度、程度 は増強し、その後のQOLを大きく低下させる一 因となる。また、これまで子宮体癌再発低リスク 群におけるリンパ節郭清術の治療的意義は証明さ れておらず、上記診断的意義のみにとどまる ${ }^{1,5)}$ リンパ節転移の有無を含め、いかに効率よくリス ク因子を評価するかがその手術の最大の目的にな ると思われる。

現行のガイドライン ${ }^{1)}$ 上の再発低リスク群子宮 体癌では傍大動脈リンパ節郭清は省略可能である とされている。正確な進行期の決定と術後療法の 決定に有用とする報告は多い1)。したがって近年、 上記記載を受けて再発低リスク群子宮体癌早期例
に対する手術術式が全国的に見直され始め、開腹 による単純子宮全摘、両側付属器切除および骨盤 リンパ節郭清術を行い傍大動脈リンパ節郭清を省 略する施設が増加傾向にある。しかし、この場合

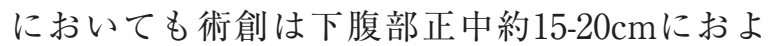
び、その侵襲は決して小さくない。

一方、昨今の腹腔鏡下手術の進歩発展は著しく、 もはや婦人科良性疾患の大多数が腹腔鏡下手術に よって対応可能であるといっても過言ではない。 年々低侵襲手術に対する期待と需要が高まってい る中、欧米では子宮体癌においてLAP2などの大 規模試験が行われ、子宮体癌に対する腹腔鏡下手 術の安全性に関する論文が相次いで報告され た ${ }^{6.7)}$ 。開腹移行例が多いとの問題点は指摘されて いるものの、開腹術と同等の安全性が得られ且つ 低侵襲という点で腹腔鏡下手術の優位性が報告さ れている。そこで、今回我々は子宮体癌早期例に 対しTLH、BSO、骨盤リンパ節摘出術の導入を 開始した。

当科では良性疾患に対するTLHも、原則全例 前方または側方アプローチで尿管と子宮動脈を同 定し、その走行を確認した後に子宮動脈を結紮、 シーリングで処理している。さらに、開腹の悪性 疾患手術時に閉鎖神経の走行など、骨盤リンパ節 郭清時特有の骨盤内の解剖を把握し手術に臨ん だ。リンパ節摘出の範囲については、これまでの 報告に基づき決定した。竹島ら ${ }^{4)}$ は子宮体癌の骨 盤内リンパ節転移の研究において、(1)筋層浸潤 $1 / 2$ 未満の症例でのリンパ節転移は $2.3 \%$ (2)リンパ 節転移が 1 個のみ認められる症例では内腸骨転移 が最も多く、次いで外腸骨節、閉鎖節への転移が 多かったとし、内腸骨節を経由する流路が早期に は重要であり、リンパ節郭清の際、十分の注意が 必要であると報告している。したがって、早期子 宮体癌に対する手術という観点から、近位端は尿 管と総腸骨動脈と交差する部位まで、遠位端は下 腹壁静脈分枝部ないしは無名静脈のレベルまでと し、外腸骨節、閉鎖節、内腸骨節を取り残しのな いようこれらを中心に、外ソケイ上節近位側から 総腸骨節遠位側までを摘出した。下肢リンパ浮腫 
発生を減らすため、上記以外のリンパ節摘出は行 わなかった。

全例子宮マニピュレーターは使用しなかった。

Evidenceとしてはそしいが、悪性疾患の手術に おいてno touch isolation techniqueは重要と考え る。安藤ら ${ }^{2)}$ は子宮マニピュレーターは病巣を直 接刺激するのを回避するために使用しないと述べ ている。しかし、内膜症の強固な癒着を伴う例や 多発筋腫の症例においてはマニピュレーターを使 用しない場合、今回の症例 $4 、 5$ のように、特に 子宮後方の手術操作に困難を伴う場合がある。手 術時間が延びるとともに、後に述べるDVT発生 の懸念もあり、円勒帯吊り上げ以外の何らかの代 替手段が必要かもしれない。

1 例においてヒラメ筋静脈にDVTの発生を認 めた。現在当科では、開腹手術においても腹腔鏡 下手術においても、術前のエコー検査にてDVT が見られなかった場合、弾性ストッキングと下肢 の間歇的空気圧加圧装置を使用して、DVT予防 対策としている。悪性疾患の腹腔鏡下手術では、 低分子ヘパリン投与も 1 つのオプションと考える が、これまでの報告(6) では、DVTの発生に開腹 術と腹腔鏡下手術とで有意差はなく、今後の症例 数の蓄積による評価が待たれるところである。

\section{まとめ}

後腹膜腔内の解剖に十分注意して、良性疾患に 対する腹腔鏡下子宮全摘術および開腹による悪性 疾患に対する手術を踏まえて施行すれば実施可能 と思われる。また、治療成績を損なうことなく低 侵襲手術を導入していくために、手技の向上と症 例数の蓄積による今後の治療成績の検討を要する と考える。

本論文の要旨は第 51 回日本産科婦人科内視鏡学 会（大阪）で発表した。

\section{参考文献}

1 ) 日本婦人科腫瘍学会/編:子宮体癌治療ガイドライン 2009年版;金原出版

2 ）産婦人科内視鏡手術スキルアップ 編集・日本産科婦 人科内視鏡学会 改訂第二版 全腹腔鏡下広沉性子宮全 摘術 安藤正明、金尾祐之 pp114-124, 2010

3 ) 安藤正明、出浦伊万里、三木通保他:腹腔鏡下子宮全 摘術 産科と婦人科2009; 増刊号76Suppl.: 243-253.

4 ) 竹島信宏、梅沢聡、清水敬生他:子宮体癌骨盤内リン パ節転移に関する研究 日産婦誌1994,46, 883-888
5 ) Todo Y, Kato H, Kaneuchi M et al.: Survival effect of para-aortic lymphadenectomy in endometrial cancer (SEPAL study) : a retrospective cohort analysis. Lancet 2010; 375: 1165-72.

6 ) Walker JL, Piedmonte MR, Spirtos NM, et al.: Laparoscopic compared with laparotomy for comprehensive surgical staging of uterine cancer: gynecologi oncology group study LAP2. J Clin Oncol 2009; 27: 5331-5336.

7 ) Kornblith AB, Huang HQ, Walker JL, et al.: Quality of life of patients with endometrial cancer undergoing laparoscopic international federation of gynecology and obstetrics staging compared with laparotomy: a gynecologic oncology group study. J Clin Oncol 2009; 27: 5337-5342.

8) Matsuoka S, Kikuchi I, Kitade M, Kumakiri J, Jinushi M, Tokita S, Takeda S.: Utility of an organ retraction sponge (endoractor) in gynecologic laparoscopic surgery. J Minim Invasive Gynecol. 2011; 18: 507-11. 